\title{
Report of the workshop "Urban Public Services"
}

Synthèse de l'atelier "Service publics urbains"

Han van Dijk and Roch L. Mongbo

\section{(2) OpenEdition Journals}

Electronic version

URL: http://journals.openedition.org/apad/155

DOI: $10.4000 /$ apad. 155

ISSN: 1950-6929

Publisher

LIT Verlag

\section{Printed version}

Date of publication: 1 December 2002

\section{Electronic reference}

Han van Dijk and Roch L. Mongbo, "Report of the workshop "Urban Public Services" », Bulletin de I'APAD [Online], 23-24 | 2002, Online since 15 December 2006, connection on 23 September 2020. URL : http://journals.openedition.org/apad/155 ; DOI : https://doi.org/10.4000/apad.155

This text was automatically generated on 23 September 2020

Bulletin de l'APAD 


\title{
Report of the workshop "Urban Public Services"
}

\author{
Synthèse de l'atelier "Service publics urbains"
}

Han van Dijk and Roch L. Mongbo

\section{EDITOR'S NOTE}

Reporter : Han van Dijk. Discussant : Roche Mongbo.

1 Six papers were presented during this workshop. A seventh paper also belonged to this workshop (Van Der Geest), but was presented at the plenary session. The programme was extremely full, since we had only four hours for this whole workshop. The audience was large and despite the fact that the workshop lasted until almost $7 \mathrm{pm}$, everybody participated fully in the discussions until the end.

2 The common theme concerned the current crisis in urban public service provision. There was no example of a well-functioning system except for the situation of Dar-es-Salaam in the 1960s and 1970s, when the city did not yet have its current size. A variety of reasons was put forward for this state of affairs.

- The lack of legitimacy of local governments, so that no management system can be enforced upon the population;

- The rural background of many urban people. They have another perspective on public services, of space and on the costs of urban public service management ;

- The lack of interest in the public good, and the contradiction between perceptions of public and private space and the appropriate way of managing public and private space ;

- Bad management of urban public services, which on its turn is due to :

- Low salaries that lead to a low level of motivation of staff ;

- Incompetence of management staff ;

- Ethnical or political appointments of staff ;

- Sabotage by the population ;

- Low recovery rate of costs. Sometimes even government departments do not pay their bills ; 
- Poverty. The resource base of the countries involved is not sufficient to afford a sophisticated system of urban public service management.

During the discussion a number of themes re-emerged :

- Some people argued that since a long time there has been no urban public service management, since it has de facto been privatized, through budget cuts (because of structural adjustment programs), bad management. Even when there is a system that is supposed to provide services, people have to manage by themselves because of the deficiencies of the system.

- Therefore, urban public services have become something that only can be afforded by the rich. The poor do not have access to public services whatsoever.

- People always engage in public service management out of a private interest. So, for research (and policy making) we need a renewed focus on strategic behaviour of all kind of actors/stakeholders. From this follows a methodological imperative focusing firstly on what may be labeled the political economy of urban public service management, and secondly the way in which actors operate within this context and what the y say that they are doing. A third methodological imperative for research is that we should be transparent and clear about how things are working. Researchers should not focus on how things ought to be but instead on how they are. Lastly, an important point for research is the functioning of hierarchical relations, not only between those who use urban public services, but also within the neighbourhood, public service department. How are tasks positions and resources divided ? Who takes decisions ? Who executes the decisions? Are rules enforced or not?

- Another recurrent theme was the level of poverty. What can African societies afford in terms of urban public service management ? Success during the colonial period was often based on repression by the colonial authorities, and for example in Tanzania during the Nyerere epoch on the basis of a strong political will and ideology. Can this be replicated without sufficient resources?

- The question was also posed whether the situation was really so bad compared with the past. The cities were in general much smaller and there was no electricity and no sewage systems. Colonial authorities did not invest that much. If we look at the present rate of growth of African cities, tremendous investments are needed in urban infrastructure and public service management. For West Africa alone, the Club du Sahel estimates that around \$ 300 billion is needed, in water provision systems, sewage systems, solid waste management and electricity. If we look at what is already functioning we should not underestimate the rate of investment.

-We should take a fresh look at initiatives from below, and learn lessons from the experiences gained in that domain.

\section{AUTHORS}

\section{HAN VAN DIJK}

African Studies Centre. 


\section{ROCH L. MONGBO}

UNB-FSA, BP 526, Cotonou, Bénin. 